\title{
SKRINING KEMAMPUAN BAHASA ANAK PRA SEKOLAH : A PILOT PROJECT
}

\author{
Hafidz Triantoro Aji Pratomo, Arif Siswanto, Windiarti Dwi \\ Purnaningrum \\ Kementerian Kesehatan Politeknik Kesehatan Surakarta Jurusan Terapi Wicara
}

\begin{abstract}
Language, Pre School, Screening. Language skills are important for a child to be able to receive information and knowledge at school and in his home environment. This child's language skills should be an important concern of all elements involved with child education, including speech therapists in an effort to monitor the child's language development before entering school. This study aims to find out the language skills profile of pre-school children aged 4-6 years. Participants were recruited from Surakarta Kindergarten with a total of 36 children to participate in this study with an age range between 4-6 years. Screening is given to participants. It is the screening result that will reflect the receptive and expressive language profile of the child. There are six test items that can be used to screen the language skills of pre-school children: simple commands, expressive vocabulary, color names, answer questions, sentence memory, and digit memories. Internal correlation of simple command grain $r=0.791$ $(p=0.000)$, expressive vocabulary grain $r=0.749(p=0.000)$, the item named color $r$ $=0.739(p=0.000)$, the item answered $r=0.754(p=0.000)$ item memory sentence $r=$ $0.879(p=0.000)$, and the item memory digit $r=0.816(p=0.000)$. The value of internal validity or correlation between items in the language development screen is good enough because all correlated items have correlations with low probability values.
\end{abstract}

Keywords: Language, Pre School, Screening

Abstrak : Bahasa, Pra Sekolah, Skrining. Kemampuan bahasa menjadi kunci bagi seorang anak untuk dapat menerima informasi dan ilmu pengetahuan di sekolah maupun di lingkungan rumahnya. Kemampuan bahasa anak ini harus menjadi perhatian penting semua elemen yang terlibat dengan pendidikan anak, termasuk terapis wicara dalam upaya untuk memonitor perkembangan bahasa anak sebelum masuk ke sekolah. Penelitian ini bertujuan untuk mengetahui profil kemampuan bahasa anak pra sekolah usia 4-6 tahun. Partisipan direkrut dari TK Surakarta dengan jumlah 36 anak untuk berpartisipasi dalam penelitian ini dengan rentang usia antara 4-6 tahun. Skrining diberikan kepada partisipan. Hasil skrining itulah yang akan mencerminkan profil kemampuan bahasa reseptif dan ekspresif anak. Terdapat enam butir tes yang bisa digunakan untuk skrining kemampuan bahasa anak usia pra-sekolah yakni perintah sederhana, kosakata ekspresif, menamai warna, menjawab pertanyaan, memori kalimat, dan memori digit. Korelasi internal butir perintah sederhana $r=0.791(p=0.000)$, butir kosakata ekspresif $\mathrm{r}=0.749(\mathrm{p}=0.000)$, butir menamai warna $\mathrm{r}=0.739(\mathrm{p}=0.000)$, butir menjawab pertanyaan $\mathrm{r}=0.754(\mathrm{p}=0.000)$, butir memori kalimat $\mathrm{r}=0.879(\mathrm{p}=0.000)$, dan butir memori digit $\mathrm{r}=0.816(\mathrm{p}=0.000)$. Nilai validitas internal atau korelasi antar item 
dalam skrining perkembangan bahasa cukup baik karena semua item yang dikorelasikan memiliki korelasi dengan nilai probabilitas yang rendah.

Kata Kunci: Bahasa, Pra Sekolah, Skrining

\section{PENDAHULUAN}

Di Indonesia, penelitian yang terfokus pada kemampuan bahasa pada anak pra-sekolah masih sangat terbatas sehingga tidak heran jika di Indonesia cukup sulit untuk menemukan data profil kemampuan bahasa anak pada kurun waktu tertentu, karena data yang ada sebagian besar dirancukan dengan kemampuan bicara. Sebagaimana diketahui bahwa kemampuan bahasa berbeda dengan kemampuan bicara. Setidaknya penelitian ini mengawali dibukanya penelitian selanjutnya tentang upaya untuk mendapatkan data yang akurat tentang profil kemampuan bahasa anak pra-sekolah. Sebagai gambaran, insidensi dan prevalensi permasalahan bahasa pada anak telah banyak ditelusuri dengan penelitian. King et al. (2005) menemukan $10 \%$ dari 513 anak berusia 3 tahun mengalami gangguan bahasa. Penelitian lain berhasil menemukan bahwa prosentase gangguan bahasa dialami oleh 18,7\% dari 1113 anak yang menjadi sampel penelitian (Okalidou \& Kampanaros, 2001). Chevrie-Muller et al. (2005) menemukan bahwa permasalahan bahasa pada anak berusia 3,5 lebih banyak dialami oleh anak laki-laki dibandingkan anak perempuan. Mereka juga menemukan bahwa gangguan bahasa lebih banyak ditemukan pada anak yang memiliki latar belakang pendidikan keluarga yang rendah. Penelitian tersebut dilakukan dengan melakukan pemeriksaan pada 2059 anak. Penelitian lain tentang gangguan bahasa juga dilakukan oleh McLeod \& Harrison (2009). Penelitiannya mencoba menggali informasi tentang jumlah anak usia 4-5 tahun yang mengalami gangguan bahasa di Australia dengan sampel 4983 anak. Penelitian dilakukan dengan menggunakan laporan orangtua (parents report) dan laporan guru (teacher reports). Dari hasil pengumpulan data terdapat $13 \%$ anak usia 4-5 tahun memiliki skor bahasa di bawah rata-rata.

Apabila kita bandingkan dengan fakta di Indonesia, Insidensi dan prevalensi anak dengan permasalahan bahasa akan sulit kita temui. Sebagai contoh penelitian atau survey yang membahas tentang kesehatan secara umum telah dilakukan Kementerian Kesehatan Republik Indonesia pada tahun 2013 dengan nama Riset Kesehatan Dasar (Riskesdas). Dalam riset tersebut, salah satu bagian yang cukup menarik adalah angka kecacatan. Apabila kita telaah maka permasalahan bahasa tidak termasuk ke dalam suatu istilah "kecacatan". Riset tersebut telah menampilkan prevalensi anak berusia 24 sampai dengan 59 bulan dengan kondisi kecacatan yang terdiri dari tuna netra, tuna wicara, down syndrome, tuna daksa, bibir sumbing dan tuna rungu (Kementerian Kesehatan, 2013). Data tersebut cukup mengusik dikarenakan kita belum bisa mendapatkan informasi secara mendalam berapakah angka prevalensi anak dengan permasalahan bahasa karena memang belum tergali hingga sejauh itu.

Sumber eviden lain menyebutkan bahwa kebutuhan suatu pemeriksaan baik formal maupun informal menjadi 
kebutuhan utama dalam upaya pengembangan profesi. Sebagai profesi yang memiliki bidang garap gangguan komunikasi dan menelan, sudah seharusnya seorang terapis wicara melakukan tindakan dimulai dari proses asesmen sampai dengan intervensi secara profesional. Kenyataan di lapangan dijumpai tidak sedikit terapis yang mengabaikan proses asesmen bukan karena tidak mampu melakukan melainkan karena instrumen yang digunakan untuk melakukan asesmen tidak ada. Kita ketahui bersama bahwa sebagian besar instrumen pemeriksaan terapi wicara masih dalam bahasa Inggris. Hal ini tentunya menyulitkan karena kultur bahasa yang berbeda antara bahasa Indonesia dan Bahasa Inggris. Sebagai contoh, McLeod dan Verdon (2014) telah melakukan review instrumen asesmen dari 30 asesmen bicara di luar bahasa Inggris. Yang cukup ironi adalah instrumen pemeriksaan atau instrumen evaluasi tidak ada satupun yang berbahasa Indonesia.

Keberadaan instrumen pemeriksaan meskipun bersifat informal merupakan titik tolak yang baik dalam upaya deteksi dini. Keakuratan dalam menentukan keputusan profesional tidak terlepas dari upaya pembandingan antara norma normal dengan temuan data yang diperoleh dari hasil asesmen. Sejauh ini, para profesional hanya melakukan deteksi dini dengan menggunakan DDST. Dalam instrumen tersebut telah mencakup beberapa aspek dari bahasa, namun demikian untuk kedalaman setiap item bahasa yang dinilai tidak bisa merepresentasikan data dengan presisi yang baik.

Dasar pertimbangan peneliti untuk menargetkan pada anak usia pra-sekolah adalah pada masa inilah kemampuan bahasa anak mengalami perkembangan yang pesat. Pada masa pra-sekolah ini pula, proses perolehan dan pembentukan bahasa baik dari aspek fonologi hingga aspek pragmatik terjadi dengan sangat masif. Harrison \& McLeod (2010) menyatakan bahwa pada masa awal anakanak proses perkembangan bahasa cukup pesat sehingga sangat perlu untuk ditingkatkan. Di sisi lain, intervensi yang terlambat akan berakibat pada munculnya masalah-masalah yang berkaitan dengan permasalahan bahasa misalnya permasalahan sosial, psikis, dan belajar.

Dari penjelasan di atas, kita dapat menarik beberapa kesimpulan. Pertama, aspek bahasa merupakan komponen yang sangat penting dalam proses tumbuh kembang anak. Kedua, ketiadaan instrumen asesmen merupakan masalah yang harus segera diselesaikan. Ketiga, upaya deteksi dini menjadi kunci dalam program preventif dan habilitatif. Tiga kesimpulan tersebut menarik peneliti untuk melakukan penelitian dengan judul Skrining Kemampuan Bahasa Anak Prasekolah: A Pilot Project. Penelitian ini dikatakan sebagai sebuah proyek pilot karena akan digunakan sebagai dasar untuk dilakukannya penelitian kemampuan bahasa anak berikutnya dengan skala yang lebih besar di masa mendatang.

\section{METODE PENELITIAN}

\section{Desain Penelitian}

Penelitian ini termasuk jenis penelitian kuantitatif. Rancangan penelitian ini adalah deskriptif kuantitatif dengan pendekatan cross sectional. Penelitian ini termasuk jenis penelitian deskripsi yakni dengan melakukan pengukuran variabel pada saat tertentu. 
Penelitian ini dilakukan pada bulan Maret 2017 sampai dengan bulan September 2017 di TK ABA Surakarta.

\section{Populasi dan Sampel}

Populasi penelitian ini adalah anak-anak berusia 4-7 tahun yang bersekolah di TK ABA Surakarta. Pengambilan sampel dilakukan dengan total sampling.

\section{Instrumen Pengumpulan Data}

Instrumen penelitian yang akan digunakan dalam penelitian ini adalah kuesioner dan tes informal.

\section{Analisis Data}

Analisis data dilakukan hanya dengan menggunakan analisis univariat. Univariat merupakan analisis yang digunakan untuk menguji variabel tunggal. Analisis univariat dilakukan untuk mengetahui distribusi frekuensi tentang karakteristik sampel.

\section{HASIL PENELITIAN}

\section{Statistik Deskriptif}

Hasil penelitian ini diuraikan dalam bentuk statistik deskriptif. Gambaran statistik deskriptif penelitian digambarkan dalam bentuk distribusi frekuensi yang terbagi berdasarkan kelas, jenis kelamin anak, pendidikan ibu, pekerjaan ibu, pekerjaan bapak, dan ukuran keluarga. Gambaran distribusi frekuensi penelitian dapat dilihat pada tabel 1 di bawah ini
Tabel 1

Distribusi Frekuensi Penelitian

\begin{tabular}{|c|c|c|c|}
\hline Variabel & Klasifikasi & $\mathrm{N}$ & Persen \\
\hline \multirow[t]{4}{*}{ Kelas } & A1 & 7 & 19.4 \\
\hline & A2 & 13 & 36.1 \\
\hline & B1 & 8 & 22.2 \\
\hline & B2 & 8 & 22.2 \\
\hline \multirow[t]{2}{*}{ Jenis kelamin } & Laki-laki & 21 & 58.3 \\
\hline & Perempuan & 15 & 41.7 \\
\hline \multirow{6}{*}{$\begin{array}{l}\text { Pendidikan } \\
\text { Ibu }\end{array}$} & SMP & 3 & 8.3 \\
\hline & SMA & 20 & 55.6 \\
\hline & Diploma I & 1 & 2.8 \\
\hline & Diploma III & 4 & 11.1 \\
\hline & Sarjana & 7 & 19.4 \\
\hline & Magister & 1 & 2.8 \\
\hline \multirow{7}{*}{$\begin{array}{l}\text { Pendidikan } \\
\text { Bapak }\end{array}$} & SMP & 2 & 5.6 \\
\hline & SMA & 17 & 47.2 \\
\hline & Diploma I & 1 & 2.8 \\
\hline & Diploma III & 5 & 13.9 \\
\hline & Sarjana & 6 & 16.7 \\
\hline & Magister & 2 & 5.6 \\
\hline & Kosong & 3 & 8.3 \\
\hline \multirow[t]{6}{*}{ Pekerjaan Ibu } & Buruh & 1 & 2.8 \\
\hline & Guru & 2 & 5.6 \\
\hline & Ibu Rumah & 20 & 55.6 \\
\hline & $\begin{array}{c}\text { Tangga } \\
\text { Karyawan } \\
\text { Swasta }\end{array}$ & 8 & 22.2 \\
\hline & $\begin{array}{l}\text { Pegawai Negeri } \\
\text { Sipil }\end{array}$ & 1 & 2.8 \\
\hline & Wirausaha & 4 & 11.1 \\
\hline
\end{tabular}

\section{Kosakata Reseptif}

Bagian kosakata reseptif memuat 10 item. Hasil pengambilan data dari 36 anak. Hasil analisis validitas diperoleh hasil bahwa 3 dari 10 item valid untuk digunakan. Hasil uji validitas kosakata reseptif dapat diketahui dari tabel 2 di bawah ini. Sedangkan hasil analisis uji reliabilitas item kosakata reseptif dengan menggunakan uji Alpha Cronbach diketahui nilai reliabilitas sebesar -0.037. 
Tabel 2

Hasil Uji Validitas Kosakata Reseptif

\begin{tabular}{clcc}
\hline No. & Item & Nilai & Keterangan \\
\hline 1 & Kucing & 0 & Tidak Valid \\
2 & Kuda & 0 & Tidak Valid \\
3 & tempat tidur & 0.214 & Tidak Valid \\
4 & Kursi & 0 & Tidak Valid \\
5 & es krim & 0 & Tidak Valid \\
6 & Roti & 0 & Tidak Valid \\
7 & Apel & 0 & Tidak Valid \\
8 & makanan & 0.381 & Valid \\
9 & pakaian & 0.755 & Valid \\
10 & mainan & 0.535 & Valid \\
\hline
\end{tabular}

\section{Pemahaman Kalimat}

Bagian pemahaman kalimat memuat 10 item. Pemilihan gambar untuk bagian pemahaman kalimat diadaptasi dari tes bahasa terstandar yakni Preschool Language Scale 4 (PLS-4) (Zimmerman et al., 2002). Hasil pengambilan data diperoleh sebesar 36 anak. Hasil analisis validitas diperoleh hasil bahwa 7 dari 10 item valid untuk digunakan. Hasil uji validitas pemahaman kalimat dapat diketahui dari tabel 3 di bawah ini. Sedangkan hasil analisis uji reliabilitas bagian pemahaman kalimat dengan menggunakan uji Alpha Cronbach diketahui nilai reliabilitas sebesar 0.463 .

Tabel 3

Hasil Uji Validitas Pemahaman Kalimat

\begin{tabular}{|c|c|c|c|}
\hline No. & Item & Nilai & Keterangan \\
\hline 1 & $\begin{array}{l}\text { Anak laki-laki makan es } \\
\text { krim }\end{array}$ & 0.128 & Tidak Valid \\
\hline 2 & $\begin{array}{l}\text { Anak laki-laki sedang } \\
\text { mandi }\end{array}$ & 0.337 & Valid \\
\hline 3 & $\begin{array}{l}\text { Anak perempuan turun } \\
\text { tangga }\end{array}$ & 0.430 & Valid \\
\hline 4 & $\begin{array}{l}\text { Anak perempuan bermain } \\
\text { bola }\end{array}$ & 0.337 & Valid \\
\hline 5 & Krayon yang berantakan & 0.033 & Tidak Valid \\
\hline 6 & $\begin{array}{l}\text { Seekor kelinci sedang tidur } \\
\text { di dalam lubang }\end{array}$ & 0.604 & Valid \\
\hline 7 & $\begin{array}{l}\text { Seekor anjing mengejar } \\
\text { ayam }\end{array}$ & 0.206 & Tidak Valid \\
\hline 8 & Nenek mencium kakek & 0.584 & Valid \\
\hline 9 & Biskuit yang masih utuh & 0.711 & Valid \\
\hline 10 & $\begin{array}{l}\text { Anak laki-laki bermain } \\
\text { boneka besar }\end{array}$ & 0.540 & Valid \\
\hline
\end{tabular}

\section{Mengikuti Perintah Sederhana}

Bagian perintah sederhana terdiri dari 9 item. Hasil pengambilan data diperoleh sebesar 36 anak. Hasil analisis validitas diperoleh hasil bahwa 9 dari 9 item valid untuk digunakan. Hasil uji validitas pemahaman perintah sederhana dapat diketahui dari tabel 4 di bawah ini. Sedangkan hasil analisis uji reliabilitas bagian pemahaman perintah sederhana dengan menggunakan uji Alpha Cronbach diketahui nilai reliabilitas bagian perintah sederhana sebesar 0.878 .

\section{Tabel 4}

Hasil Uji Validitas Pemahaman Perintah Sederhana

\begin{tabular}{clcc}
\hline No. & \multicolumn{1}{c}{ Item } & Nilai & Ket \\
\hline 1 & Ambil buku & 0.570 & Valid \\
2 & Angkat pensil & 0.457 & Valid \\
3 & Ambil krayon warna merah & 0.542 & Valid \\
4 & Ambil buku dan berikan padaku & 0.766 & Valid \\
5 & Ambil pensil dan buat lingkaran & 0.652 & Valid \\
6 & Letakkan pensil di atas buku, & 0.727 & Valid \\
& kemudian ambil bukunya & & \\
7 & ambil kertas kemudian lipatlah & 0.898 & Valid \\
8 & $\begin{array}{l}\text { Ambil buku kemudian buka, dan } \\
\text { berikan pensil padaku } 0.852\end{array}$ & Valid \\
9 & Ambil kertas, kemudian lipatlah, & 0.865 & Valid \\
& dan berikan padaku & & \\
\hline
\end{tabular}

\section{Kosakata Ekspresif}

Instrumen kosakata ekspresif terdiri dari 17 item. Hasil pengambilan data diperoleh sebesar 36 anak. Hasil analisis validitas diperoleh hasil bahwa 15 dari 17 item valid untuk digunakan. Hasil uji validitas kosakata ekspresif dapat diketahui dari tabel 5 di bawah ini. Hasil analisis uji reliabilitas bagian kosakata ekspresif dengan menggunakan uji Alpha Cronbach diketahui nilai reliabilitas bagian kosakata ekspresif sebesar 0.819 . 
Tabel 5

Hasil Uji Validitas Kosakata Ekspresif

\begin{tabular}{|c|c|c|c|}
\hline \multicolumn{4}{|c|}{ DMN } \\
\hline No. & Item & Nilai & Keterangan \\
\hline 1 & Mata & 0 & Tidak Valid \\
\hline 2 & Mulut & 0.268 & Tidak Valid \\
\hline 3 & Kaki & 0.807 & Valid \\
\hline 4 & Hidung & 0.574 & Valid \\
\hline 5 & Sepatu & 0.807 & Valid \\
\hline 6 & Bola & 0.714 & Valid \\
\hline 7 & Biskuit & 0.521 & Valid \\
\hline 8 & Kucing & 0.484 & Valid \\
\hline 9 & Burung & 0.605 & Valid \\
\hline 10 & Balon & 0.807 & Valid \\
\hline 11 & Susu & 0.457 & Valid \\
\hline 12 & Sendok & 0.491 & Valid \\
\hline 13 & Televisi & 0.807 & Valid \\
\hline 14 & Gunting & 0.807 & Valid \\
\hline 15 & Sepeda & 0.807 & Valid \\
\hline 16 & Panci & 0.501 & Valid \\
\hline 17 & Gelas & 0.482 & Valid \\
\hline
\end{tabular}

\section{Menamai Warna}

Bagian menamai warna terdiri dari 9 item. Hasil pengambilan data diperoleh sebesar 36 anak. Hasil analisis validitas diperoleh hasil bahwa 9 dari 9 item valid untuk digunakan. Hasil uji validitas menamai warna dapat diketahui dari tabel 6 di bawah ini. Hasil analisis uji reliabilitas bagian kosakata ekspresif dengan menggunakan uji Alpha Cronbach diketahui nilai reliabilitas bagian menamai warna sebesar 0.844 .

Tabel 6

Hasil Uji Validitas Menamai Warna

\begin{tabular}{clcc}
\hline No. & \multicolumn{1}{c}{ Item } & Nilai & Keterangan \\
\hline 1 & Merah & 0.651 & Valid \\
2 & Hijau & 0.627 & Valid \\
3 & Kuning & 0.734 & Valid \\
4 & Biru & 0.653 & Valid \\
5 & Hitam & 0.754 & Valid \\
6 & Putih & 0.691 & Valid \\
7 & Merah muda & 0.600 & Valid \\
8 & Coklat & 0.754 & Valid \\
9 & Jingga & 0.791 & Valid \\
\hline
\end{tabular}

\section{Menjawab Pertanyaan}

Bagian menjawab pertanyaan terdiri dari 6 item. Hasil pengambilan data diperoleh sebesar 36 anak. Hasil analisis validitas diperoleh hasil bahwa 6 dari 6 item valid untuk digunakan. Hasil uji validitas menjawab pertanyaan dapat diketahui dari tabel 7 di bawah ini. Hasil analisis uji reliabilitas bagian menjawab pertanyaan dengan menggunakan uji Alpha Cronbach diketahui nilai reliabilitas bagian menjawab pertanyaan sebesar 0.844 .

Tabel 7.

Hasil Uji Validitas Menjawab

Pertanyaan

\begin{tabular}{clcc}
\hline No. & \multicolumn{1}{c}{ Item } & Nilai & Keterangan \\
\hline 1 & Siapa namamu? & 0.527 & Valid \\
2 & Berapa umurmu? & 0.785 & Valid \\
3 & Di mana rumahmu? & 0.712 & Valid \\
4 & Mengapa kamu harus & 0.754 & Valid \\
& makan? & & \\
5 & Bagaimana cara kamu & 0.597 & Valid \\
& menggosok gigi? & & \\
6 & Kapan kamu tidur & 0.695 & Valid \\
\hline
\end{tabular}

\section{Memori Kalimat}

Bagian memori kalimat terdiri dari 10 item. Hasil pengambilan data diperoleh sebesar 36 anak. Hasil analisis validitas diperoleh hasil bahwa 10 dari 10 item valid untuk digunakan. Hasil uji validitas memori kalimat dapat diketahui dari tabel 8 di bawah ini. Hasil analisis uji reliabilitas bagian memori kalimat dengan menggunakan uji Alpha Cronbach diketahui nilai reliabilitas bagian memori kalimat sebesar 0.908 . 
Tabel 8

Hasil Uji Validitas Memori

Kalimat

\begin{tabular}{clcc}
\hline No. & Item & Nilai & Keterangan \\
\hline 1 & $\begin{array}{l}\text { Ani naik } \\
\text { sepeda }\end{array}$ & 0.620 & Valid \\
2 & $\begin{array}{l}\text { Adik sedang } \\
\text { menagis }\end{array}$ & 0.766 & Valid \\
3 & $\begin{array}{l}\text { Budi berangkat } \\
\text { ke sekolah } \\
\text { Ibuku bernama } \\
\text { Ani }\end{array}$ & 0.813 & Valid \\
5 & $\begin{array}{l}\text { Ibu sedang } \\
\text { menyapu lantai }\end{array}$ & 0.720 & Valid \\
6 & $\begin{array}{l}\text { Kakak sedang } \\
\text { membersihkan }\end{array}$ & 0.736 & Valid \\
7 & $\begin{array}{l}\text { kamar } \\
\text { Ayah bekerja } \\
\text { sebagai dokter }\end{array}$ & 0.736 & Valid \\
8 & $\begin{array}{l}\text { Kaki kakak } \\
\text { kotor sekali } \\
\text { Budi berangkat } \\
\text { sekolah naik } \\
\text { sepeda } \\
\text { Ibu guru } \\
\text { memberikan } \\
\text { PR } \\
\text { Matematika }\end{array}$ & 0.7691 & Valid \\
\hline & 0.565 & Valid \\
\hline & & Valid \\
\hline
\end{tabular}

\section{Memori Digit}

Bagian memori digit dilakukan untuk mengetahui kapasitas kognitif anak. Bagian ini memuat 10 item. Hasil pengambilan data diperoleh sebesar 36 anak. Hasil analisis validitas diperoleh hasil bahwa 10 dari 10 item valid untuk digunakan. Hasil uji validitas memori digit dapat diketahui dari tabel 9 di bawah ini. Hasil analisis uji reliabilitas bagian memori digit dengan menggunakan uji Alpha Cronbach diketahui nilai reliabilitas bagian memori digit sebesar 0.869 .

Tabel 9

\section{Hasil Uji Validitas Memori Digit}

\begin{tabular}{clcc}
\hline No. & \multicolumn{1}{c}{ Item } & Nilai & Keterangan \\
\hline 1 & $4-7$ & 0.795 & Valid \\
2 & $6-3$ & 0.733 & Valid \\
3 & $6-4-1$ & 0.678 & Valid \\
4 & $3-5-2$ & 0.681 & Valid \\
5 & $8-3-7$ & 0.678 & Valid \\
6 & $4-7-2-9$ & 0.706 & Valid \\
7 & $3-8-5-2$ & 0.769 & Valid \\
8 & $7-2-6-1$ & 0.748 & Valid \\
9 & $3-1-8-5-9$ & 0.560 & Valid \\
10 & $4-8-3-7-2$ & 0.528 & Valid \\
\hline
\end{tabular}

\section{PEMBAHASAN}

\section{Validitas Internal}

Validitas merupakan komponen yang harus ada dalam sebuah instrumen tes pemeriksaan kemampuan bahasa dan bicara. Validitas merupakan kemampuan tes untuk mengukur apa yang seharusnya diukur (Shipley \& McAfee, 2009). Nilai validitas yang kecil menunjukkan bahwa tes tidak bisa digunakan untuk mengukur kemampuan yang diharapkan untuk diukur. Hasil analisis data dari delapan item dalam instrumen skrining perkembangan bahasa ini menunjukkan hasil yang berbeda. Hasil dari delapan item dalam instrumen skrining bahasa diketahui memiliki nilai reliabilitas yang berbeda. Kesimpulan nilai reliabilitas setiap item dapat dilihat pada tabel 10 .

\section{Tabel 10}

Nilai Reliabilitas Item

\begin{tabular}{clc}
\hline No. & Item Instrumen & Nilai Reliabilitas \\
\hline 1 & Kosakata reseptif & -0.037 \\
2 & Pemahaman & 0.463 \\
& kalimat & \\
3 & Perintah sederhana & 0.878 \\
4 & Kosakata ekspresif & 0.819 \\
5 & Menamai warna & 0.844 \\
6 & Menjawab & 0.844 \\
& pertanyaan & 0.908 \\
7 & Memori kalimat & 0.869 \\
8 & Memori digit & mengindikasikan
\end{tabular}
bahwa analisis untuk mengetahui validitas internal tidak bisa dilakukan untuk setiap item pemeriksaan dalam instrumen skrining perkembangan bahasa ini. Item yang harus dikeluarkan untuk dianalisis nilai validitasnya adalah kosakata reseptif dan pemahaman kalimat. Sedangkan item yang bisa dilakukan analisis validitas internal adalah perintah sederhana, kosakata ekspresif, menamai warna, menjawab pertanyaan, memori kalimat, dan memori digit. Hasil analisis validitas 
untuk setiap butir tes kecuali perintah sederhana karena sesuai dengan nilai ratarata. Jika dilihat lebih lanjut, diketahui nilai total di bawah rata-rata sehingga interpretasi kemampuan bahasa dari hasil skrining didapatkan bahwa kemampuan bahasa anak di bawah rata-rata.

\section{KESIMPULAN DAN SARAN}

Terdapat enam butir tes yang bisa digunakan untuk skrining kemampuan bahasa anak usia pra-sekolah yakni perintah sederhana, kosakata ekspresif, menamai warna, menjawab pertanyaan, memori kalimat, dan memori digit.

Dari penelitian ini didapatkan suatu norma nilai kemampuan bahasa anak usia pra-sekolah yang diperoleh dari analisis univariat.

Hasil penelitian menemukan bahwa kebutuhan untuk melakukan penelitian yang bertujuan untuk menemukan alat ukur terstandarisasi terutama untuk pemeriksaan kemampuan bahasa sangat diperlukan. Perlu ada stimulus kebijakan anggaran untuk dilakukannya penelitian lanjutan. Selain itu, diharapkan ada penelitian lanjutan yang menambah ruang lingkup penelitian menjadi lebih luas agar lebih mudah dalam menggeneralisasikan hasil penelitian.

\section{DAFTAR RUJUKAN}

Chevrie-Muller, C., Watier, L., Arabia, J., Arabia, C., \& Dellatolas, G. (2005). Teachers'screening for language and behavior difficulties in 2059 children aged 3.5 years. Revue $d$ Epidemiologie et de Sante Publique, 53, 645-657.

Harrison, LJ., \& McLeod, S. (2010). Risk and protective factors associated with speech and language impairment in a nationally representative sample of 4- to 5years old children. Journal of Speech, Language, and Hearing Research. 53, pp.508-529.

Kementerian Kesehatan Republik Indonesia. (2013). Riset Kesehatan Dasar (RISKESDAS 2013). Jakarta: Badan Penelitian dan Pengembangan Kesehatan Kementerian Kesehatan Republik Indonesia.

King, TM., Rosenberg, LA., Fuddy, L., McFarlane, E., Sia, C., \& Duggan, AK. (2005). Prevalence and early identification of language delays among at-risk three year olds. Journal of Developmental and Behavioral Pediatrics, 26 (4), pp.293-303.

McLeod, S., \& Harrison, LJ. (2009). Epidemiology of speech and language impairment in a nationally representative sample of 4- to 5year old children. Journal of Speech, Language, and Hearing Research. 52 (5), pp.1213-1229.

McLeod, S., \& Verdon, S. (2014). A review of 30 speech assessments in 19 languages other than English. American Journal of SpeechLanguage Pathology. 23, pp.708723.

Okalidou, A., \& Kampanaros, M. (2001). Teacher perceptions of communication impairment at screening stage in preschool children living in Patras, Greece. International Journal of Language and Communication Disorders, 36, 489-502.

Shipley, KG, \& McAfee, JG. (2009). Assessment in speech language pathology: A resources manual. San 
34 Jurnal Keterapian Fisik, Volume 3, No 1, Mei 2018, hlm 01-57

Diego: Singular Publishing Group, Inc.

Zimmerman, IL., Steiner, VG., \& Pond, RE. (2002). Preschool Language Scale. $\left(4^{\text {th }}\right.$. Ed $)$. San Antonio: The Psychological Corporation. 